\title{
Effects of double-stranded RNA on virulence of Paecilomyces fumosoroseus (Deuteromycotina: Hyphomycetes) against the silverleaf whitefly, Bemisia tabaci strain B (Homoptera: Aleyrodidae)
}

\author{
Andréia Cristiane Souza Azevedo ${ }^{1}$, Daniel Ricardo Sosa-Gómez ${ }^{2}$, Marcos Rodrigues Faria ${ }^{3}$ \\ and Maria Helena Pelegrinelli Fungaro ${ }^{1}$
}

\begin{abstract}
Bands of double-stranded RNA (dsRNA) were detected in three out of twelve isolates of Paecilomyces fumosoroseus. Identity of these bands was confirmed by RNAse, DNAse and S1 nuclease treatments. The cure of dsRNA for one isolate (P92) was successfully carried out for a single conidium subculture. Isogenic strains, with or without dsRNA, were submitted to virulence tests against the whitefly Bemisia tabaci strain B. In contrast to findings for some phytopathogenic fungi, these dsRNA fragments did not cause hypovirulence in P. fumosoroseus.
\end{abstract}

\section{INTRODUCTION}

Whiteflies are found worldwide and cause considerable damage to a variety of high-value crops (Gerling and Mayer, 1996). The entomopathogenic fungus Paecilomyces fumosoroseus (Wise) Brown \& Smith is an important natural control agent of homopteran insects, and has become a commercial product in Mexico and the United States. This fungus is associated with Bemisia tabaci in different global regions (Lacey et al., 1996), including Brazil, where strain B has been observed on vegetables and soybean (Sosa-Gomez, D.R. and Faria, M.R. de, unpublished results). Also in Brazil, recent whitefly outbreaks have been recorded (França et al, 1996) and, since chemical control has proven inefficient, use of entomopathogenic fungi as mycoinsecticides has been considered. Double-stranded RNAs (dsRNA) are commonly found in fungi, and some are associated with virus-like particles (Michelmore and Hulbert, 1987). Effects of dsRNA on fungal pathogenicity have been studied mainly in plant pathogenic species, and their hypovirulence to hosts is well documented (Castanho et al., 1978; Anagnostakis and Day, 1979; Pusey and Wilson, 1982; Boland, 1992). The only study done so far on entomopathogenic fungi effects employed Metarhizium flavoviride (= M. anisopliae var. acridum) and the grasshopper Rhammatocerus schistocercoides (Martins et al., 1999). In the present communication we report the occurrence of dsRNA elements in $P$. fumosoroseus isolates, and whether the dsRNA affected their virulence with respect to the silverleaf whitefly, $B$. tabaci strain B.

\section{MATERIAL AND METHODS}

The geographic origin, insect hosts and isolation data of twelve $P$. fumosoroseus strains used in this study are presented in Table I. Cultures were maintained on complete medium agar plates as described by Pontecorvo et al. (1953). Incubation was performed at $28^{\circ} \mathrm{C}$. Mycelia were ground with liquid $\mathrm{N}_{2}$ using a mortar and pestle; genomic DNA was extracted according to Bogo et al. (1996). For RNAse A digestion, the enzyme (Gibco Life Technologies) was added to $3 \mu \mathrm{g}$ total nucleic acids for a final concentration of $8 \mu \mathrm{g} / \mathrm{ml}$ in $100 \mathrm{mM}$ Tris- $\mathrm{HCl}, 10 \mathrm{mM}$ EDTA, $\mathrm{pH} 7.5$ and incubated at $37^{\circ} \mathrm{C}$ for $30 \mathrm{~min}$. For $\mathrm{S} 1$ nuclease digestion $35 \mathrm{U}$ of enzyme (Gibco Life Technologies) was added per $\mu \mathrm{g}$ of total nucleic acids; the reaction was performed according to supplier's instructions. For DNAse digestion, the samples were treated with enzyme (Pharmacia) at $20 \mu \mathrm{g} / \mathrm{ml}$ in $30 \mathrm{mM} \mathrm{MgCl}_{2}$ at $37^{\circ} \mathrm{C}$ for $20 \mathrm{~min}$. To test for dsRNA transmission through conidia, ten singleconidial isolates were obtained from P92. A conidial suspension was spread over a water-agar plate and incubated overnight. Agar blocks bearing single conidia with short germ tubes were aseptically cut and transferred to CM tubes.

For virulence test, melon leaves, hybrid AF682, were removed from plants and put in glass vials $(7 \times 3.5 \mathrm{~cm})$, with petiole immersed in tap water. Leaves were kept individually inside plastic cups $(14 \times 9 \mathrm{~cm})$ with a screened top, in an incubator regulated to $27 \pm 1{ }^{\circ} \mathrm{C}, 70 \pm 5 \% \mathrm{RH}$ and at a 12-h photophase. Each leaf was infested by 18 adult couples of B. tabaci biotype B (Hemiptera: Aleyrodidae) for $26 \mathrm{~h}$. Six days after adult removal, 1- and 2-instar nymphs

\footnotetext{
${ }^{1}$ Centro de Ciências Biológicas, Universidade Estadual de Londrina,Caixa Postal 6001, 86051-970 Londrina, PR, Brasil. Send correspondence to M.H.P.F. Fax: +55-43-371-4207. E-mail: hfungaro@sercomtel.com.br ${ }^{2}$ CNPSo/EMBRAPA, Londrina, PR, Brasil. ${ }^{3}$ Cenargen/Embrapa, Brasília, DF, Brasil.
} 
Table I - Origin of P. fumosoroseus isolates.

\begin{tabular}{|llll|}
\hline Isolates & & Host & Location \\
\hline CNPSo-Pf77(ARSEF5154) & P. fumosoroseus & Bemisia argentifolii & Brazil \\
CNPSo-Pf78(ARSEF5155) & P. fumosoroseus & B. argentifolii & Brazil \\
CNPSo-Pf80(ARSEF5157) & P. fumosoroseus & B. argentifolii & Brazil \\
CNPSo-Pf81(ARSEF5158) & P. fumosoroseus & B. argentifolii & Brazil \\
CNPSo-Pf85 & P. fumosoroseus & B. argentifolii & Brazil \\
CNPSo-Pf92(ARSEF3638) & P. fumosoroseus & Soil & Brazil \\
CNPSo-Pf93(ARSEF2956) & P. fumosoroseus & Spaethiella sp. & Brazil \\
CNPSo-Pf125(ARSEF2658) & P. fumosoroseus & Trialeurodes vaporariorum & United States \\
CNPSo-Pf126(ARSEF3083) & P. fumosoroseus & B. tabaci & United States \\
CNPSo-Pf121(ARSEF3303) & P. fumosoroseus & Bemisia sp. & Mexico \\
CNPSo-Pf124(ARSEF3660) & P. fumosoroseus & B. tabaci & United States \\
CNPSo-Pf127(ARSEF3699) & P. fumosoroseus & B. tabaci & India \\
\hline
\end{tabular}

were selected through observation under a dissecting microscope and ink-marked with a spot near their position. For spraying conidial suspension, a Potter Spray Tower (Burkard Manufacturing, Hertfordshire, England) operating at $12.5 \mathrm{psi}$ and applying $2 \mathrm{ml}$ conidial suspension (1.0 $\mathrm{x} 10^{7} / \mathrm{ml}$ ) per leaf was used. In the control treatment, a $0.1 \%$ Tween 80 solution was applied. Incubation conditions were the same as mentioned above. Assessments were performed 12 days post-spray, when numbers of live and dead nymphs and adults were determined.

\section{RESULTS AND DISCUSSION}

The CNPso-Pf80, CNPso-Pf81 and CNPso-Pf92 P. fumosoroseus isolates showed extra-bands after electrophoretic separation of undigested nucleic acids (Figure 1). These bands proved to be dsRNA, as evidenced by sensitivity to RNAse in buffer with low salt concentration, and insensitivity to DNAse and S1 nuclease, which had no effect on these bands but eliminated the single-stranded RNA (ssRNA). Based on number and molecular size, two distinct banding patterns were observed. Isolates CNPsoPf80 and CNPso-Pf81 were identical in pattern bands, showing three bands of $1.7,1.3$ and $0.5 \mathrm{~kb}$. The isolate CNPso-Pf92 showed three bands of 4.5, 3.5 and $3.2 \mathrm{~kb}$. This polymorphism type has also been observed in other fungi species, including entomopathogenic fungi, e.g., Metarhizium anisopliae (Bogo et al., 1996) and Metarhizium flavoviride (=M. anisopliae var. acridium) (Martins et al., 1999). Band profile similarity of P80 and P81 isolates is probably because they are from the same geographic region and, consequently, infected by the same virus. Isolates CNPso-Pf77, CNPso-Pf78, CNPso-Pf85, CNPso-Pf93, ARSEF 2658, ARSEF 3303, ARSEF 3083, ARSEF 3660 and ARSEF 3589 did not contain any detectable extra-bands.

Inability to transmit dsRNA by simple infection or transduction is the major obstacle to directly analyzing the role of these elements in regulating virulence and related traits. So, the relationship of these genetic elements to virulence variability has mostly been inferred from correlative evidence, supported in some cases by curing and transmission experiments (Nuss and Koltin, 1990). In attempts to eliminate dsRNA from various fungal species, several treatments have been used, e.g., chlorate selection of nit mutants, incubation at high temperature, hot water exposure, antibiotics, acridine dye, single conidium subculture, hyphal tip transfer, UV-irradiation, and cycloheximide treatment (Pusey and Wilson, 1982; Fulbright, 1984; Hunst et al., 1986; Kousik et al., 1994; Elias and Cotty, 1996). Although these methods would fail in some

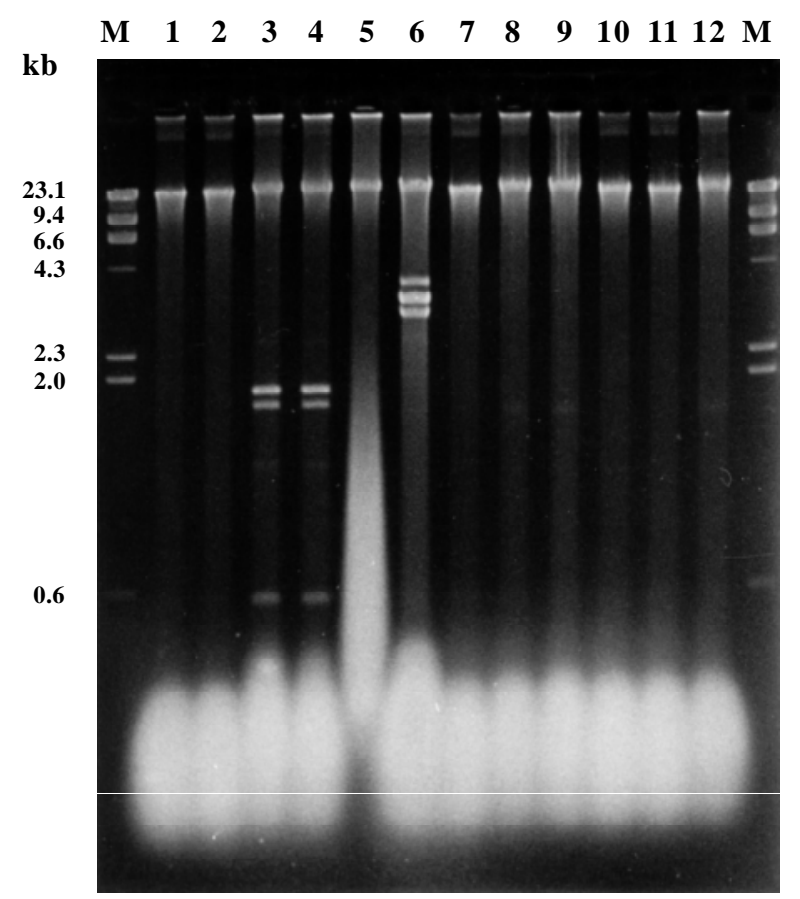

Figure 1 - Agarose gel electrophoresis of total nucleic acid extracted from Paecilomyces fumosoroseus. Lane M, Molecular markers (HindIII cut $\lambda$ DNA); Lane 1, CNPso-Pf77; Lane 2, CNPso-Pf78; Lane 3, CNPso-Pf80; Lane 4, CNPso-Pf81; Lane 5, CNPso-Pf85; Lane 6, CNPso-Pf92; Lane 7, CNPsoPf93; Lane 8, ARSEF 2658; Lane 9, ARSEF 3083; Lane 10, ARSEF 3303; Lane 11, ARSEF 3660; Lane 12, ARSEF 3589. 
Table II - Virulence tests of P92 strain with dsRNA and P92 strain without dsRNA. Data represent percentage of mortality 12 days post-spray conidial suspension.

\begin{tabular}{|lcc|}
\hline Strain & P92 strain with dsRNA & P92 strain without dsRNA \\
\hline RI & 73.9 & 71.7 \\
RII & 92.1 & 77.3 \\
RIII & 75.9 & 87.8 \\
M \pm SD & $80.6^{\mathrm{a}} \pm 10.0$ & $78.9^{\mathrm{a}} \pm 8.1$ \\
\hline
\end{tabular}

a Means followed by the same letter are not different according to Tukey's test $(\mathrm{P}<0.05)$; RI, RII and RIII are replicates.

entomopathogenic species (Martins et al., 1999), we did obtain cured strains of the $\mathrm{P} 92$ isolate by single conidium subculture. Four out of ten single-conidial P92 isolates showed no dsRNA banding profiles, indicating that dsRNA components were not perfectly transferred during asexual subculture. The absence of dsRNA in the four cured strains after five successive subcultures assured cure.

Bioassays using CNPSo-Pf92 with and without dsRNA fragments against the whitefly were performed, in order to investigate if the dsRNA in P. fumosoroseus induces hypovirulence. Results of the bioassays are presented in Table II. Although this isolate was obtained from soil, its virulence is as high as that observed by Vidal et al. (1997) for isolates obtained from different whitefly species. Comparison of mean mortality by the Tukey test showed no statistical differences among isolates, indicating that these dsRNA fragments did not cause hypovirulence in P. fumosoroseus, in contrast to those found in some phytopathogenic fungi (Castanho et al., 1978; Ghabrial, 1980; Brasier, 1983; Naiki and Cook, 1983; Fulbright, 1984), but in accordance with findings for the entomopathogenic fungus M. flavoviride (Martins et al., 1999). Absence of hypovirulence effects of dsRNA for P. fumosoroseus has been shown for the first time in the present work.

\section{ACKNOWLEDGMENTS}

This investigation was supported by PRONEX and CNPq. A.C.S.A. was the recipient of a CNPq fellowship.

\section{RESUMO}

Bandas de dsRNA foram detectadas em três dos doze isolados de Paecilomyces fumosoroseus. A identidade destas bandas foi provada através de tratamentos com RNAse, DNAse e S1 nuclease. A cura do dsRNA para um dos isolados (P92) foi obtida através do isolamento de colônias monospóricas. Linhagens isogênicas, com e sem dsRNA, foram submetidas ao teste de virulência contra a mosca branca Bemisia tabaci biotipo B. Ao contrário do que ocorre para vários fungos fitopatogênicos, os fragmentos de dsRNA não causaram hipovirulência em P. fumosoroseus.

\section{REFERENCES}

Anagnostakis, S.L. and Day, P.R. (1979). Hypovirulence conversion in Endothia parasitica. Phytopathol. 69: 1226-1229.

Bogo, M.R., Queiroz, M.V., Gimènez, D.M., Azevedo, J.L. and Schrank, A. (1996). Double-stranded RNA and isometric virus-like particles in the entomopathogenic fungus Metarhizium anisopliae. Micol. Res. 100: 1468-1472.

Boland, G.J. (1992). Hypovirulence and double-stranded RNA in Sclerotinia sclerotiorum. Can. J. Plant Pathol. 14: 10-17.

Brasier, C.M. (1983). A cytoplasmatically transmitted disease of Ceratocystis ulmi. Nature 305: 220-222

Castanho, B., Butler, E.E. and Shepherd, R.J. (1978). The association of double stranded RNA with Rhizoctonia decline. Phytopathol. 68: 1515-1519.

Elias, K.S. and Cotty, P.J. (1996). Incidence and stability of infection by double-stranded RNA genetic elements in Aspergillus section flavi and effects on aflatoxigenicity. Can. J. Bot. 74: 716-725

França, F.H., Villas Bôas, G. and Branco, M.C. (1996). Ocorrência de Bemisia argentifolii Bellows \& Perring (Homoptera: Aleyrodidae) no Distrito Federal. An. Soc. Entomol. Bras. 25: 369-372.

Fulbright, D.W. (1984). Effects of eliminating dsRNA in hypovirulent Endothia parasitica. Phytopathol. 74: 722-724.

Gerling, D. and Mayer, R. (1996). Bemisia 1995: Taxonomy, Biology, Damage, and Management. Intercept, Andover.

Ghabrial, S.A. (1980). Effects of fungal viruses on their hosts. Ann. Rev Phytopathol. 18: 441-461.

Humber, R.A. (1992). Collection of Entomopathogenic Cultures. ARSEF Catalog of Strains. USDA-ARS Publication 110, Ithaca, NY. Update in http:www.ppru.cornell.edu/mycology/insect mycology.html

Hunst, P.L., Latterell, F.M. and Rossi, A.E. (1986). Variation in doublestranded RNA from isolates of Pyricularia oryzae. Phytopathol. 76 : 674-678.

Kousik, C.S., Snow, J.P. and Valverde, R.A. (1994). Comparison of doublestranded RNA components and virulence among isolates of Rhizoctonia solani AG-1 IA and AG-1 IB. Phytopathol. 84: 44-49.

Lacey, L.A., Fransen, J.J. and Carruthers, R. (1996). Global distribution of naturally occurring fungi of Bemisia, their biologies and use as biological control agents. In: Bemisia 1995: Taxonomy, Biology, Damage, and Management (Gerling, D. and Mayer, R., eds.). Intercept, Andover

Martins, M.K., Furlaneto, M.C., Sosa-Gomez, D.R., Faria, M.R. and Fungaro, M.H.P. (1999). Double-strand RNA in the entomopathogenic fungus Metarhizium flavoviride. Curr. Genet. 36: 94-97.

Michelmore, R.W. and Hulbert, S.H. (1987). Molecular markers for genetic analysis of phytopathogenic fungi. Ann. Rev. Phytopathol. 25 $383-404$.

Naiki, T. and Cook, R.J. (1983). Factors in loss of pathogenicity in Gaeumannoomyces graminis var. tritici. Phytopathol. 73: 1653-1656.

Nuss, D.L. and Koltin, Y. (1990). Significance of dsRNA genetic elements in plant pathogenic fungi. Ann. Rev. Phytopathol. 28: 37-58.

Pontecorvo, G., Roper, J.A., Hemmons, L.M., Macdonald, K.D. and Bufton, A.W.J. (1953). The genetics of Aspergillus nidulans. Adv. Genet. 5: 141-148.

Pusey, P.L. and Wilson, C. (1982). Detection of double stranded RNA viruses in Ceratocystis ulmi. Phytopathol. 73: 470-474.

Vidal, C., Lacey, L.A. and Fargues, J. (1997). Pathogenicity of Paecilomyces fumosoroseus (Deuteromycotina: Hyphomycetes) against Bemisia argentifolii (Homoptera: Aleyrodidae) with the description of a bioassay method. J. Econ. Entom. 90: 765-772.

(Received August 26, 1999) 
